\title{
Communicational and Message Theory Concepts and Notions
}

\author{
Adrian Nicolescu ${ }^{1, *}$, Mirela Teodorescu ${ }^{2}$ \\ ${ }^{1}$ University of Craiova, 13 A. I. Cuza Street, 200585, Craiova, Romania \\ ${ }^{2}$ Independent Researcher, Craiova, Romania \\ *E-mail address: a86iorgulescu@yahoo.com
}

\begin{abstract}
Communicational and Message Theory Concepts and Notions is a book of high intellectual elevation and high expression of ideas of Professor Stefan Vlăduţescu from University of CraiovaRomania, published by Editura Sitech, Craiova, Romania. Communication sciences refers to the schools of scientific research of human communication. This perspective follows the logical positivist tradition of inquiry; most modern communication science falls into a tradition of post-positivism. Thus, communication scientists believe that there is an objective and independent reality that can be accessed through the method of scientific enquiry. A scientist researcher following the zetetic method formulates the question then immediately sets to work making observations and performing experiments to answer that question. Communicational and Message Theory Concepts and Notions is a book about communication sciences in which professor Vlăduţescu approaches the subjects by zetetic method. The research was also combined with empirically traditional method to get both quantitative and qualitative results.
\end{abstract}

Keywords: communicational act; communicational fact; communicational discourse; persuasion; conviction

\section{INTRODUCTION}

Professor Ştefan Vlăduţescu is a reputed specialist in communication sciences, journalism, hermeneutics, reviewing with several books published in this area, being concerned by the diversity of the aspects offered by this segment of science, that are interrelated by notions of sociology, psychology, philosophy, literature, journalism, public relations, computer science, mathematics controlling them skillfully in his books.

Communication-as-an-Universe can be organized along 15 axes, and hence we can refer to the organization grid as the Communication Axes Matrix- Standard. Furthermore, can be differentiated four hard axes which are defined for the communication domain: communication ontology-A1, communication epistemology-A2, communication methodology-A3, and communication axiology-A4. At the same time, are retained the other 11 axes as qualifying, differentiating axes and soft axes: communication history-A5, communication psychology-A6, communication sociology-A7, communication anthropologyA8, communication hermeneutics-A9, communication praxeology-A10, communication 
ethics-A11, communication logics-A12, communication ecology-A13, communication philosophy-A14, and communication law-A15.

Professor Vlăduţescu argues in the favor of the thesis that communication as an academic discipline is facing many uncertainties. One of these is the uncertainty regarding the status. Nuclear question about the status of the communication: the study of communication is a theory or a science, is a weak cogitative system or a strong cogitative system? "We distinguish five causes that determined communication study to remain to this day a weak cogitative system: the effervescence of the theoretical-scientific and practical researches in a knowledge area full of promises; heavy coagulation of a cogitative communication community; refusal of the rule; articulation of communicational thinking as "weak thinking" "weak thought" (G. Vattimo); and the delay in the development of the communication ontology".

Communication is a new science if we refer to it appearance moment, but the concept was perceived in all other sciences. Communication is an event composed of varying proportions of communicative acts and facts. "The man communicates whether he will or he will not." When he is communicating intentionally, his manifestation is a communicative act. Communicational facts occurs mainly in nonverbal communication.

Communicational and Message Theory Concepts and Notions is structured in 18 chapters that covers communication concepts belonging of communication axes.

\section{COMMUNICATIONAL EVENT}

In the first 3 chapters of the book, Communicational and Message Theory Concepts and Notions, the professor Stefan Vlăduţescu, developed the concepts of communicational act and fact, as well of the communicational event. They were used by specialists, without a rigor they would not be criticized, because it belongs partly of maturity reached by communication theory, by its critical phase. M. Heidegger showed that understanding of the world (science, generally) runs in each area a road in three steps: the step of simplistic understanding, that of "artistic" understanding and finally, the step of the critical understanding. Philosophy, would be reached after a long evolution only simultaneous with Immanuel Kant to its critical phase ("Critique of Pure Reason," "Critique of Practical Reason", "Critique of Judgment"). "This step, asserts Stefan Vlăduţescu, have touched the communication and information theory today after "Criticism of communication" by Lucien Sfetz" (Vlăduţescu, 2006). These "critics" are not deconstructed steps but judicious analysis, positive of learning objects. "Criticism" so is and thus has to be understood: in the classical sense "to judge, to discern" coming from the Greek "krinein" (Vlăduţescu, 2009).

In each communicational exercise there are information act and information fact. Information and transinformation are constituted inside of the registry of "sensitivity" of the consumer. They are determined by the force of the meanings passing the "exam" of communicational grid criteria. The problem of the communicational event arises only if it is relevant to the aims, objectives and interests that shape cognitive and articulates structural criteria for selection of grid composition. If they have not the relevant force, they are not taken into account, they are not selected as acts or facts. Relevancy is the threshold of significance.

The act and fact are communicational approaches of productive gnosis practice or consuming, mentions professor Vlăduţescu, so there is only as event, manifest and not virtual. Information -Virtuality is itself an event, i.e. a fact. The idea that information should have a 
structure "built" and itself as a "construction" it is not new. It looks newer than it actually is, just by expanding the number of those who adopt (Vlăduţescu, 2009).

Communication is constituted as assembly of facts of language that the process protagonists put in the work targeting construction or modification of a poetic or physical mood, ideas, thoughts, feelings or material-physical reality of any kind. Within the process there is a transfer of targeted message meanings: knowledge, ideas, feelings, beliefs, opinions, experiences. These aim the installation, modification or consolidation of some behaviors, attitudes, value systems, opinions or positions.

Orientation is the intentional part of communication and it consists of motivations, interests, revealed or hidden motives. Depending on orientation are built the "programs" of communication instance. Communication, as an interactive construction, involves practices of thinking, knowledge and language. Within the society, there is not a separate, autotelic domain of communication and could not imagine such a field than theoretical, because ontogenetic and phylogenetic takes part of the essence of society. Communication has its impress in establishment, organization and functioning of society and of all activities that derive from them. Social interaction that gives coherence of the society requires a communicative interaction, and social facts and acts are implicitly communicative: any action based on an idea and expressing, in one way or another, by herself performing, the communicational idea from where it goes.

"The message will automatic be accompanied by additional negative messages: indifference, lack of warmth, etc. Therefore, in order to protect the true message, the productive thinking has to put it into a discourse in which to inoculate also security instructions. Putting the message in language is shaped by a cultural inertia of literature, philosophical, theological, mythological, etc. To ensure viability within a discourse, to the message should be additional messages implanted by the way of secondary codes. Insertion of language-cogitation of the message is based on safety and formatting of the formulation. Everyone who wants to be just must be exaggerated. The message is unable to transfer as message. The message always comes after. The message comes after the discourse was over" concludes professor Vlăduţescu. To set oneself just to write the message is a failure on the language borders movement. The language is felt to be tight when the message is great (Vlăduţescu, 2009).

The next 2 chapters are dedicated to discourses analysis, for ceremonial discourse and impositive discourse. "What can be thought, can be thought founded. The thought thing finds its basis either appealing to an impositive mode (argumentation or demonstration) or ceremonial-oracular-protocolar, connecting to the evidence that even the thing promises, permits it and advances it.

It communicates to share an axiological organized experience when someone intends to agree on values whose meaning is intended to be harmonized, acting lingual for their communization. Argumentative communication aims the transfer and opinions communication, getting a favorable attitude or a certain behavior. The argumentation and demonstration are impositive methods and are used in the space of knowledge and cognition horizon, they acts in justification contexts".

The author makes a comprehensive analysis of ceremonial and impositive discourse, by the specific methods used by them over the time, arguing and supporting his statements by an impressive volume of citations. 


\section{COMMUNICATION AXIOMS}

In the $6^{\text {th }}$ chapter, the author presents and demonstrates the communication axioms that defines the completeness and consistency of communication as science. The idea of communication axioms belongs to Palo Alto School. Each one of axioms is analyzed from communication point of view argued with quoted of reputed scientists and a lot of examples of real life because "noncomunication is impossible".

Remarkable in this chapter is the fact that the author emphasize the professor Mihai Dinu's contribution to initial set of five axioms. The Romanian professor Dinu, evaluated, analyzed the existent axioms and added another two completing the set.

\section{COMMUNICATION INCIDENCES}

In the next 6 chapters professor Vlăduţescu defines in his synthetically characteristic style of bringing important ideas from whole universe of documentation, the important incidences of communication concepts such as communicational circumstance, communicational contract, social communicational competence, communication object vs. discourse object, communication instance, feed device through feedback and feed forward. These concepts define communication.

The circumstance concept decides what we are capable to explain and how we are able to communicate, it decides what we can observe and what we are able to understand, creating first of all a communicational relationship. Communication constitutes the fundamental form of interaction. Any communication is based on a contract of communication understood as implicit or explicit installed protocol and which generates the development of any communicational interaction.

The interaction control is detained by that one who has clear the constitution and functioning of the communication contract. The social communicational competence is that one which assures the success in society. Social skills allow establishment of social manners, understood as patterns of social behavior.

Social manners are behaviors that make visible the individuals socially competent. Solidarity, empathy, kindness and thoughtfulness are principal social competences. Communication object is a generation of meanings that goes beyond the sphere of the discourse that includes it. These meanings coagulate in some stakes. The communication stakes assembly forms the message. Ultimately, the object of communication is the message; it is also the subject of the discourse.

The communication instance decides and allows the system to function. It is the dispatching body, production, organization, scheduling and control of communication. Discursive mechanisms are put into operation by the communication instance. Discursive strategies of summarizing, reformulation and paraphrasing, tactic argumentative-discursive procedures of demonstration, illustrating, exposing, exemplification, repetition at the level of instance are set.

Communication is related to human being whose existence is characterized by cognition. Any cognitive process subtends law-like a feed-back connection and a feed forward connection meaning a conceptual train constituted on retroaction operations and anticipation operation, establishing a connection between past, present and future. 


\section{CONVICTION AND PERSUASION}

The last six chapters are dedicated to conviction and persuasion forms of communication. This part of communication is treated with large propensity by Professor Vlăduţescu in articles, studies, books. In Vlăduţescu's professor opinion, conviction is "guided by logics", by its aspects of trust, responsibility, revalidation it determines the efficiency of communication, more even its existence but persuasion means to convince somebody to believe, to think or to want to do a certain thing, also can be a concession under the pression of a precalculated action. The methods of conviction are rational approach, argumentation, demonstration but persuasion are myth, fiction, seduction and lying. For each of them professor Vlăduţescu dedicated a chapter to describe, to define, to develop the operating system in communication field. Journalism is a domain that uses persuasion techniques either in positive or negative form. The author describes in detail the mechanisms of persuasion tools, how they handles emotions of masses, arriving at manipulation. The author asserts that: "manipulators is the tool to achieve an interest that did not belong and that is escaping him. The manipulator does not perform a manipulated interest, but a real interest. In the process of manipulation there is also a manipulated interest. Lying and fiction are easily grafted on expectations triggered by instinct; myth grafts in vulnerable place of expectations triggered by intellect, and seduction insinuates in the fictional expectations. Psychologically, therefore, the individual is vulnerable to persuasion! Through his expectations, he favors installing persuasive influence".

\section{CONCLUSION}

Communicational and Message Theory Concepts and Notions by professor Vlăduţescu is not only a book about communication science, it is a compendium by its structure and volume of information. "The overwhelming majority of research on a topic is done in absence of any consciousness of completeness of the reading and subject capitalization reference. An important part of what remains explicitly rejects the completeness according to the idea of satiety and of their enough brought by proper zetetic engagement, explorative. Remains that, in an era in which a theme in written increasingly longer, one who reads addresses on time without thought of remorse, only alleged "enough" concludes professor Vlăduţescu.

\section{References}

[1] Jozef Novak-Marcincin, Daniela Gîfu, Mirela Teodorescu, International Letters of Social and Humanistic Sciences 27 (2014) 22-33.

[2] Paula Bajdor, Iwona Grabara, Journal of Studies in Social Sciences 7(2) (2014).

[3] Ștefan Vlăduțescu (2009). Concepte și noțiuni de Comunicare și Teoria mesajului. Craiova: Editura Sitech.

[4] Andrzej Borowski, International Letters of Social and Humanistic Sciences 14 (2014) 7-17.

[5] C. E. Ciovica, F. Cristian, V.-A. Enăchescu (2011). Communication and conflict-an intercultural approach. Euromentor Journal-Studies about education. 
[6] Marin Drămnescu (2014). Argumentation for social instruction model from the perspective of social innovation. eLearning \& Software for Education.

[7] Ştefan Vlăduţescu, American International Journal of Contemporary Research 3(10) (2013).

[8] Andrzej Borowski, International Letters of Social and Humanistic Sciences 14 (2014) $33-41$.

[9] Ioan Constantin Dima, Ştefan Vlăduţescu (2012). Persuasion elements used in logistical negotiation: Persuasive logistical negotiation. Saarbrucken: LAP Lambert Academic Publishing.

[10] Daniela Gîfu, Mirela Teodorescu, Dan Ionescu, International Letters of Social and Humanistic Sciences 17 (2014) 61-69.

[11] Petre Bosun, Daniela Gîfu, Mirela Teodorescu, International Journal of Education and Research 2(3) (2014).

[12] Oprea-Valentin Buşu, Mirela Teodorescu, Daniela Gîfu, International Letters of Social and Humanistic Sciences 27 (2014) 82-93

[13] Florentin Smarandache, Ștefan Vlăduțescu, Alina Țenescu (2014). Current Communication Difficulties. Craiova/Columbus: Sitech/Zip Publishing.

[14] Andrzej Borowski, International Letters of Social and Humanistic Sciences 6 (2013) 86-90.

[15] F. Smarandache, Ș. Vlăduţescu (2014). Neutrosophic Emergences and Incidences in Communication and Information. Saarbrucken: LAP Lambert Academic Publishing.

[16] S. M. Radu, International Letters of Social and Humanistic Sciences 16 (2014) 184-193.

[17] Janusz Grabara, Michal Kolcun, Sebastian Kot, International Journal of Education and Research 2(2) (2014).

[18] Andrzej Borowski, International Letters of Social and Humanistic Sciences 4 (2013) 70-74.

[19] Ștefan Vlăduțescu, International Letters of Social and Humanistic Sciences 24 (2014) 86-94.

[20] Borowski A., International Letters of Social and Humanistic Sciences 2 (2013) 56-60.

[21] Florentin Smarandache, Ștefan Vlăduțescu (2014). Towards a Practical Communication Intervention. Revista de Cercetare si Interventie Sociala.

[22] Ştefan Vlăduţescu, European Scientific Journal 9(32) (2013).

[23] Ş. Vlăduţescu, E. M. Ciupercă (2013). Next Flood Level of Communication: Social Networks. Aachen: Shaker Verlag.

[24] Ștefan Vlăduțescu, International Letters of Social and Humanistic Sciences 10 (2014) 100-106.

[25] Ştefan Vlăduţescu, International Letters of Social and Humanistic Sciences 25 (2014) 16-24. 
[26] Florentin Smarandache, Ştefan Vlăduţescu (2014). Communication Neutrosophic Routes. Columbus, OH: Educational Publishing.

[27] Andrzej Borowski, International Letters of Social and Humanistic Sciences 3 (2013) 46-53.

[28] Ștefan Vlăduțescu, Florentin Smarandache, Daniela Gîfu, Alina Țenescu (2014). Topical Communication Uncertainties. Craiova/Columbus: Sitech/Zip Publishing.

[29] Andrzej Borowski, International Letters of Social and Humanistic Sciences 14 (2014) 7-17.

[30] Ştefan Vlăduţescu (2013). What Kind of Communication Is Philosophy. Jokull.

[31] Andrzej Borowski, International Letters of Social and Humanistic Sciences 2 (2014) 110-121.

[32] Ștefan Vlăduțescu, International Letters of Social and Humanistic Sciences 7 (2014) 8-13.

[33] J. H. Gasderell, International Letters of Social and Humanistic Science 22 (2014) 85-91.

[34] Ștefan Vlăduțescu, International Letters of Social and Humanistic Sciences 15(2) (2014) 164-170.

[35] Andrzej Borowski, International Letters of Social and Humanistic Sciences 3 (2013) 46-53.

[36] Adrian Nicolescu (2014). The role of decentralization in the Romanian public administration system: analysis, theory and models. Revista de Ştiinţe Politice. Revue des Sciences Politiques.

[37] Ștefan Vlăduțescu (2013). Principle of the Irrepressible Emergence of the Message. Jokull.

[38] G. Rajović, J. Bulatović, International Letters of Social and Humanistic Sciences 6 (2013) 24-35.

[39] Max G. Craig, Journal of Studies in Social Sciences 8(1) (2014).

[40] Ștefan Vlăduțescu, Journal of Sustainable Development Studies 6(1) (2014).

[41] M. G. Mangra, E. A. Cotoc, A. Traistaru (2013). Sustainable Economic Development Through Environmental Management Systems Implementation. Journal.

[42] Ştefan Vlăduţescu, European Scientific Journal 9(32) (2013).

[43] Andrzej Borowski, International Letters of Social and Humanistic Sciences 27 (2014) 100-110.

[44] Jason L. Powell, International Letters of Social and Humanistic Sciences 17(1) (2014) 1-60. 